\title{
Peran kehumasan Koko Jali mempertukarkan nilai keberagaman melalui wisata toleransi Kampung Sawah
}

\author{
Yesica Yuliani Clara ${ }^{1}$, Rustono Farady Marta ${ }^{2}$ \\ ${ }^{1,2}$ Universitas Bunda Mulia, Jakarta, Indonesia
}

\begin{abstract}
ABSTRAK
Indonesia dengan keanekaragamannya ternyata menjadi potensi terpendam pemicu konflik. Minimnya daya tangkap masyarakat serta kemampuan untuk memahami perbedaan budaya menimbulkan permasalahan komunikasi antarbudaya, salah satunya adalah persoalan antar agama. Aspek ini tentu memengaruhi masyarakat Indonesia dalam berkomunikasi dan berinteraksi. Apabila masyarakat kekurangan edukasi yang komprehensif mengenai budaya, serta pentingnya toleransi, dan sikap saling menghormati, maka konflik interkultural dan agama pun akan terus berlangsung. Untuk itu peneliti berkaca dari wilayah Kampung Sawah di Bekasi, dimana toleransi antarumat beragama sudah ada sejak ratusan tahun lalu, dan terus dipertukarkan, berkembang, bahkan diwariskan hingga saat ini. Peneliti menggunakan pendekatan kualitatif dengan metode studi kasus tematik, serta Teori Negosiasi Identitas Ting-Toomey. Tujuan penelitian ini untuk mengungkap proses penyampaian pesan serta nilai-nilai toleransi antar umat beragama, yang dinegosiasikan kepada remaja sebagai generasi muda penerus bangsa, melalui program Wisata Toleransi Kampung Sawah oleh komunitas Koko Jali. Hasil dari penelitian ini menunjukan bahwa Wisata Toleransi menjadi salah satu program kehumasan untuk meningkatkan pengetahuan dan awareness mengenai nilai toleransi antar agama kepada generasi muda. Melalui pemaparan yang dilakukan oleh para pemuka agama dalam sesi wisata tersebut peneliti menemukan adanya hubungan relasi kuasa dari para pemuka agama kepada peserta, sehingga terjadi penerimaan negosiasi identitas dalam diri individu. Diharapkan melalui penelitian ini, semakin banyak institusi yang menggencarkan kesadaran akan pentingnya gerakan seperti wisata toleransi di masyarakat, sehingga dapat menjaga kerukunan serta terus melestarikan warisan budaya kita, Bhineka Tunggal Ika.
\end{abstract}

Kata-kata Kunci: Negosiasi identitas; wisata toleransi; toleransi umat beragama; peran komunitas; hubungan masyarakat

\section{Koko Jali’s Public Relations Program in Diversity Values through Kampung Sawah tolerance} ABSTRACT

Indonesia, with its diversity, tends to have a potential hidden trigger for conflict. The lack of community understanding and the ability to understand cultural differences raises intercultural communication problems, one of which is inter-religious issues. This aspect certainly affects Indonesian people in communicating and interacting. Lack of comprehensive education about culture and the importance of tolerance and mutual respect would generate persistence in intercultural and religious conflicts. For this reason, researchers look at the Kampung Sawah area in Bekasi, where tolerance between religious communities has existed for hundreds of years and continues to be exchanged, developed, and even inherited until now. This research uses a qualitative approach with thematic case study methods and Ting-Toomey's Identity Negotiation Theory as the foundation. The purpose of this study is to reveal the process of delivering messages and values of tolerance between religious communities, which are negotiated between teenagers as the nation's next-generation, through the Kampung Sawah Tolerance Tourism program by the Koko Jali community. This study indicates that Tolerance Tourism is one of the public relations programs to increase knowledge and awareness about the value of interfaith tolerance to the younger generation. Through the presentations made by religious leaders in the tour session, the researchers found a power relationship between religious leaders and participants, resulting in acceptance of identity negotiations within the individual. It is hoped that through this research, more institutions will intensify awareness of the importance of movements such as tolerance tourism in society so that they can maintain harmony and continue to preserve our cultural heritage, Bhineka Tunggal Ika.

Keywords: Identity negotiation; tolerance tourism; religious tolerance; community roles; public relations

Korespondensi:Yesica Yuliani Clara, S.I.Kom. Universitas Bunda Mulia, Jln. Lodan Raya No.02, Jakarta Utara 14430.Email: Yclara26@gmail.com 


\section{PENDAHULUAN}

Aneka ragam suku/ras, budaya, bahasa, dan agama, menjadikan Indonesia sebagai negara multikultural yang bersatu padu serta berpegang pada semboyan Bhineka Tunggal Ika. Menurut badan pusat statistik ditahun 2010, data menunjukan bahwa Indonesia memiliki setidaknya 1.128 suku yang menyebar di 17 ribu pulau lebih. Keanekaragaman ini membuat Indonesia mendapat predikat salah satu negara yang paling kaya akan budaya (Santosa, 2017).

Indonesia tercatat memiliki kekayaan sangat besar baik dari segi SDA (Sumber Daya Alam) maupun SDM (Sumber Daya Manusia) nya. Inilah yang menjadikan bumi pertiwi sebagai daya tarik kuat yang menjadikan negara penguasa atau adidaya serta negara lain untuk menduduki kekuasaan di Indonesia. Luas dan strategisnya letak geografis Indonesia pun semakin memikat perhatian banyak negara di dunia. Tidak hanya kekayaan alam, tetapi warisan ratusan budaya dari sejak jaman kerajaan, hingga karya seni dari berbagai ribuan suku yang tinggal di seluruh pulau Indonesia turut menjadi daya pikat bumi pertiwi (Tamburian, 2018).

Ironinya, meski dijuluki sebagai negara multikultur, Indonesia tak lepas dengan konflik, salah satunya pertikaian antar agama. Salah satu kasus konflik antar agama yang menyebabkan korban jiwa dalam beberapa tahun terakhir adalah tragedi Jumat 1 Syawal 1436H 2015 di Karubaga, Kabupaten Tolikara, Papua (Rosyid, 2015). Tak hanya di Indonesia bagian Timur, sampai di ibukota yang terkenal dengan modernitasnya pun tak luput dari konflik, seperti pada kampanye pemilihan kepala daerah (PILKADA) pada tahun 2016 yang menyeret nama Basuki Tjahaja Purnama (AHOK) sebagai mantan Gubernur DKI Jakarta, dengan tuduhan penistaan agama (Tamburian, 2018).

Banyaknya suku, ras, agama, dan budaya, membuat masyarakat di Indonesia lebih sensitif terkait isu-isu identitas budaya seperti etnisitas dan agama. Hingga sampai ke ranah isu identitas politik, salah satunya kembali pada kasus pemilihan Gubernur Daerah Khusus Ibukota Jakarta pada 2017 silam, mayoritas penduduk di Jakarta adalah Jawa dan Muslim. Pasangan Basuki Tjahaja Purnama (Ahok) yang berasal dari etnis Tionghoa dan beragama Kristen dan Djarot Djarot Saiful Hidayat (Djarot) akhirnya menjadi sasaran sensifitas. Terjadi hasutan dalam pilkada tersebut yang beredar lewat media massa dan digital agar warga tidak memilih orang non- Jakarta, dan berasal dari etnis atau agama tertentu. Dipihak lain, pasangan Anies Baswedan (Anies) - Sandiaga Uno (Sandi) juga sempat menjadi sasaran sensifitas tersebut, karena dalam kampanye nya menggunakan istilah "pribumi" untuk menyatakan bahwa 
dirinya merupakan suku asli yang ada di Indonesia. Setelah polemik Pilkada DKI Jakarta pada tahun 2017 tersebut, konflik isu identitas semakin marak berkembang hingga keberbagai daerah di Indonesia yang menyebabkan gesekan terjadi di mana-mana. Seperti pada pemilihan gubernur Sumatera Utara pada tahun berikutnya, yakni tahun 2018 yang menggunakan kembali strategi isu identitas (Devi \& Rahardjo, 2018).

Padahal secara hukum, Indonesia mengakui 6 agama dan 1 aliran kepercayaan (Putri, 2011), yang menegaskan bahwa agama memiliki peran khusus dalam setiap kehidupan individu maupun bermasyarakat. Seperti halnya agama ditempatkan sebagai kontrol sosial serta sebagai nilai esensial kehidupan bermasyarakat. (Ismanto, Huda, \& Maulida, 2013).

Melihat hal ini, banyaknya konflik yang berkaitan dengan hubungan antarumat beragama yang terjadi di Indonesia bukan sesuatu yang baru di Indonesia. Mengingat Indonesia adalah negara yang beragam budaya, konflik semacam ini wajar terjadi. Namun tetap diperlukan kesadaran untuk saling menghargai dan toleransi pada setiap keberagaman identitas individu, termasuk perbedaan antarumat bergama agar terjalin hubungan kemasyarakatan yang harmonis (Kholisha, 2014).

Pasal 1 Declaration of Principles in Tolerance yang dibuat oleh UNESCO, menerangkan bahwa toleransi ialah sikap penghormatan, apresiasi, dan penerimaan terhadap semua perbedaan yang ada di dunia. Toleransi adalah harmonisasi dalam perbedaan, hal ini bukan hanya suatu kewajiban moral, tetapi suatu hal yang dipersyaratkan dalam bidang hukum dan politik. Secara filosofis, kata toleransi berasal dari bahasa latin yakni tolerare, mempunyai pengertian yaitu membiarkan orang lain yang memiliki pemikiran atau pandangan lain tanpa dihalang-halangi (Putri, 2011).

Ironinya, justru sebab terbesar pertikaian antar agama di Jabodetabek adalah karena kurangnya pengetahuan masyarakat tentang agama lain, yakni sebesar 40,2\% seperti pada gambar 1. Untuk itu perlu nya sebuah wadah di mana setiap individu dapat saling menukarkan informasi bahkan identitas keagamaan nya agar muncul kesepemahaman dan harmonisasi.

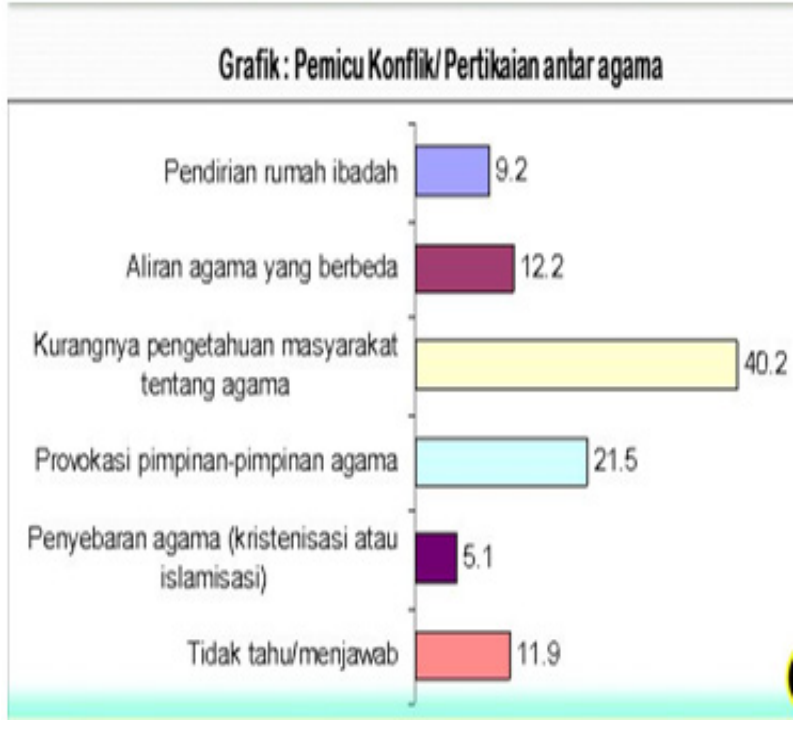

Sumber: Kementrian Dalam Negri dalam Rakornas FKUB, 2012

Gambar 1 Grafik Sebab Pertikaian Antar Agama di Jabodetabek 2012 
Identitas diri didefinisikan sebagai bentuk dari proses konstruksi refleksi diri yang terlihat, dibangun, dan disampaikan dalam rupa pesan non-verbal maupun verbal dalam suatu konteks interaksi budaya tertentu. Sedangkan negosiasi berarti interaksi transaksional yakni dalam suatu situasi antarbudaya setiap individu-individu yang terlibat didalamnya akan mempertukarkan konsep diri mereka dan memproses konsep diri orang lain.

Menurut Ting Toomey, dalam menegosiasikan identitas, individu menjalani proses di mana ia akan mengeksplorasi caracara mempertukarkan/ menegosiasikan identitas mereka terutama dalam interaksi dan komunikasi antarbudaya. Identitas seseorang merupakan produk yang dihasilkan dari interaksi sosial. Negosiasi adalah ketika kita menyatakan, memodifikasi atau menantang identifikasiidentifikasi diri kita atau orang lain sehingga muncul lah identitas atau gambaran refleksi diri (Littlejohn, 2009). Negosiasi Identitas akan efektif jika individu yang mempertukarkan indentitas mereka merasa diterima, dipahami, dan dihormati (Kurniasari, 2015).

Namun seringkali hal yang terjadi saat seorang berinteraksi dengan budaya lain, adalah hal kebalikannya, masing-masing individu akan mengalami perbedaan, ketidakrentanan, otonomi, keraguan, ketidakjelasan, dan perubahan yang mengarah pada kurang stabilnya dan kemungkinan akan perubahan, penerimaan, atau transformasi. Sedangkan pengalaman individu dari kebudayaan yang sama akan lebih dalam pada aspek keterikatan, persamaan, kejelasan, kerentanan, dan konsistensi (Sicca \& Rakhmat, 2016).

Hal tersebut kemudian dikenal dengan istilah anxiety dan uncertainty. Diperlukan keterampilan dalam mengelola anxiety dan uncertainty secara tepat agar terjalin komunikasi yang efektif. Salah satunya adalah pola pikir individu yang mindful atau mindless dalam menghadapi interaksi berbeda budaya tersebut. Langer menyatakan seseorang dengan sadar akan mencari isyarat atau simbol-simbol yang dijadikan guidance bagi dirinya untuk berperilaku dalam situasi sosial dan pola komunikasi yang berbeda bahkan baru. Namun, jika individu telah berkali-kali menghadapi situasi sosial dan pola komunikasi yang relatif sama, kesadarannya dalam berperilaku akan berkurang (mindless) (Mas’udah, 2014). Gudykunst menyatakan bahwa percakapan yang mindless dalam situasi antarbudaya akan meningkatkan anxiety dan uncertainty.

Menjadi mindful ketika berinteraksi dan berkomunikasi, artinya seseorang secara sadar mengetahui dan dapat mengakui bahwa ada beragam pandangan atau perspektif untuk menciptakan serta menginterpretasikan pesan dalam suatu situasi komunikasi. Ketika 
seseorang bersikap mindless, ia cenderung tak dapat atau sulit untuk mengakui pandangan yang beragam. Seseorang akan lebih sulit berperilaku sesuai dengan situasi yang ada dan terbatas dalam berkomunikasi dalam menghadapi lawan bicara yang berbeda, jika memiliki pandangan yang sempit dan pola pikir tertutup (close minded). Kebalikannya, jika individu berkomunikasi dengan mindful, ia akan lebih mempertimbangkan apa pandangan serta pemikiran lawan bicara yang dihadapinya dalam berkomunikasi, tidak terbatas hanya pada apa yang dipikirkannya, sehingga lebih mudah berperilaku sesuai dengan situasi dan konteks sosial yang dihadapi (Mas'udah, 2014).

Jandt mengungkapkan empat kecakapan Dalam perspektif komunikasi antarbudaya yang mindful, yaitu kecakapan komunikasi (communication skills), kekuatan kepribadian (personality strength), kesadaran budaya (cultural awareness), dan penyesuaian psikologis (psychological adjustment). Serta Langer menyebutkan sifat kepribadian yang memengaruhi komunikasi antarbudaya adalah pengungkapan diri (self-disclosure), konsep diri (self concept), pemantauan diri (self monitoring), dan relaksasi sosial (social relaxation) (Primasari, 2014).

Komunikasi antarbudaya yang mindful mewujudkan harmonisasi dan kerukukan sosial yang terpadu. Ini adalah suatu upaya dalam menegosiasikan dan mempertahankan identitas budaya tanpa menimbulkan konflik dalam masyarakat multikultural sekaligus menjadikan identitas budaya tersebut menjadi dinding pertahanan dalam menghadapi serbuan budaya global.

Komunikasi mindful akan terjalin ketika pengelolaan kecemasan dan ketidakpastian yang dihadapi antar individu berjalan dengan baik. Di samping itu, setiap individu juga harus berusaha mengurangi atau mereduksi sikap-sikap melabel budaya tertentu (stereotip), perasaan cinta budaya sendiri secara berlebihan atau fanatic (etnosentris), dan tidak berprasangka. Hal tersebut jika dilakukan dalam menjalin hubungan atau interaksi, dapat meminimalkan kesalahpahaman budaya. Selanjutnya mindful dalam komunikasi antar budaya juga akan tercapai (Suryandari, 2017).

Mindfulness dalam penjelasan TingToomey adalah penyesuaian diri dengan diri sendiri dan menjadi transparan dengan niat, motivasi, identitas sosiokultural, dan masalah kerentanan keamanan identitas pribadi Mindfullness juga menjelaskan tentang penyelarasan antarpribadi yang menjangkau proses sehubungan dengan orang lain yang berbeda secara budaya dan menawarkan perhatian, penerimaan, dan penegasan identitas yang tidak terbagi (Dalil \& Rahardjo, 2019).

Peneliti berkaca dari pola komunikasi 
warga di wilayah Kampung Sawah, Bekasi, dimana sikap toleransi yang terbentuk diwariskan turun temurun oleh nenek moyang mereka sejak ratusan tahun silam, yang akhirnya terinternalisasi dan menyatu dengan adat istiadat, sehingga menjadi suatu budaya, yakni sikap saling menjaga kerukunan dalam keberagaman antarumat beragama. Dimana Betawi Kristiani dan Katolik sudah menyatu dengan akar budaya yang sama dengan Betawi Muslim (Wahjusaputri \& Fitriani, 2016).

Berlokasi di daerah Jawa Barat, Kampung Sawah seolah menjadi distorsi dari kondisi Kota Bekasi yang sering diliput berbagai media massa maupun digital menjadi salah satu kota paling tidak toleran, terlihat dari laporan terkait isu hilangnya kebebasan pemeluk agama dalam menjalankan ritual ibadah, walaupun dalam beberapa tahun belakang kondisi toleransi di Kota ini meningkat (Noorbani, 2019). Para penggiat budaya pun sering berdialog dan bersilahturahmi dengan ketua adat membahas rencana-rencana pengangkatan ritual adat atau hal-hal menarik lain nya mengenai budaya yang ada di Kampung Sawah, melalui dialog ini, pola interaksi antar individu dapat terjadi.

Seperti yang telah dijelaskan sebelumnya, Kota Bekasi adalah salah satu kota yang paling tidak toleran di Indonesia. Hal ini terlihat dari index pada gambar 2, kota Bekasi menduduki peringkat kedua sebagai kota yang tidak toleran

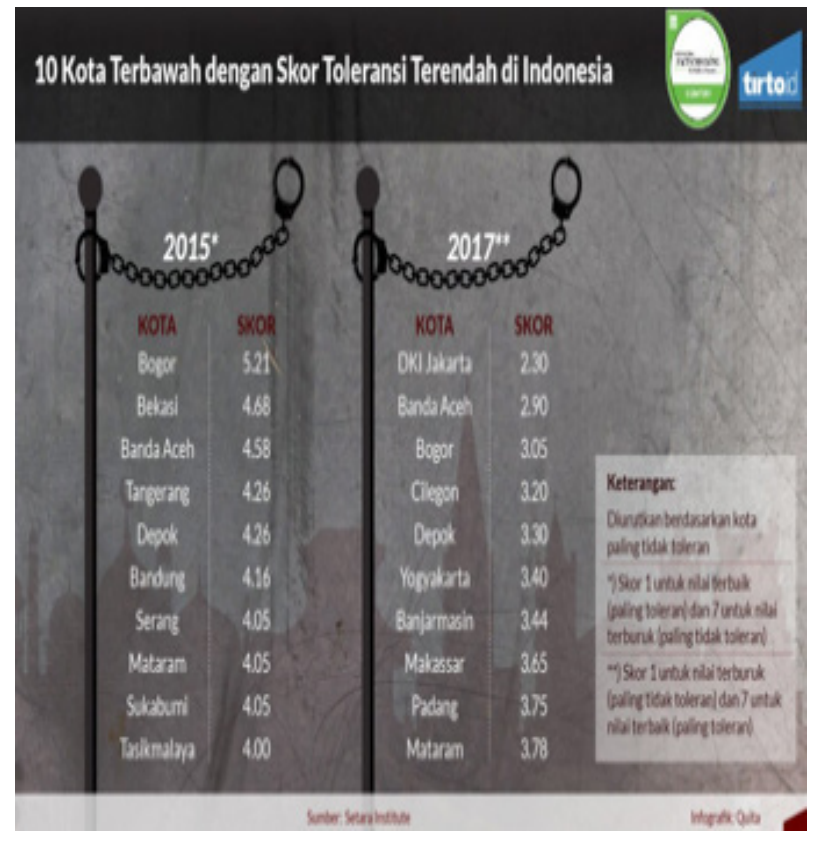

Sumber: Setara Institute dalam Tirto.id, 2018

Gambar 210 Kota Terbawah dengan Skor Toleransi Terendah di Indonesia

dengan skor 4,68, di bawah kota Bogor yang mempati posisi pertama dengan skor 5,21 pada tahun 2015. Berselang dua tahun, kota Bekasi mampu keluar dari 10 peringkat kota toleransi terendah. Berbeda dengan kota Bogor dan Banda Aceh pada tahun 2015 memiliki peringkat 1 dan 3, pada tahun 2017 masih menduduki peringkat 3 dan 2. Fakta ini menjadi hal yang menarik untuk ditelisik, yakni dengan 2 tahun Bekasi mampu meningkatkan toleransi kotanya secara signifikan

Sampai saat ini hubungan kekerabatan antar warga asli Kampung Sawah tetap terjalin bahkan erat, walau terdapat perbedaan agama. Persaudaraan ini tak melulu hanya mengenai saudara kandung atau ada hubungan darah, 
melainkan juga kerabat berbeda agama yang terjalin melalui perkawinan campur atau beda agama. Melalui kasus ini, beberapa pasangan pada akhirnya berpindah keyakinan ke agama pasangannya. Tetapi, banyak pula yang bertahan pada agama nya masing-masing (Jamaludin, 2015).

Hal ini semakin menarik ketika daerah Kampung Sawah belakangan ini mulai disorot oleh media dan diberikan julukan "Kampung Toleransi”. Selain itu, muncul pula tur budaya dan religi atau wisata toleransi ke Kampung Sawah, seperti yang diadakan oleh organisasi wirausahawan sosial di Indonesia yakni Komunitas Koko Jali. Organisasi ini memiliki spesialisasi pada masalah 'Kebhinekaan', isu nasionalisme, keberagaman budaya, serta masalah sosial dan lingkungan, yang diwujudkan dalam bentuk tur atau wisata toleransi.

Wisata toleransi yang diusung oleh Koko Jali termasuk kegiatan special event yang digunakan oleh humas dalam memperluas knowledge dan pengenalan (awareness) kepada target publiknya (Santoso \& Toruan, 2018). Fungsi kehumasan jika dikaitan dengan spesial event yang dijalankan Koko Jali melalui kegiatan khusus wisata toleransi tersebut adalah untuk (a) Menjadi fasilitator dalam memberikan edukasi dan wadah untuk mempertukarkan informasi terkait toleransi antar umat beragama secara tatap muka (langsung) dan dua arah sehingga terdapat hubungan timbal balik yang positif dengan publiknya, yakni generasi muda. Sehingga visi dan misi organisasi Koko Jali dapat tercapai (b) Kegiatan wisata toleransi ini menjadi media komunikasi sekaligus alat untuk mendapatkan publikasi positif bagi organisasi Koko Jali dan Kampung Sawah sebagai kampung toleransi. Pada akhirnya generasi muda yang menjadi target dari Koko Jali akan memperoleh pemaparan, pengetahuan, dan pengertian yang mendalam mengenai keanekaragaman budaya dan agama, serta nilai toleransi antar agama. Hal tersebut merupakan bagian dari visi utama Koko Jali, yakni memberikan layanan pendidikan yang menghargai keanekaragaman secara adil dan setara dalam pendidikan inklusif yang bermutu dan bermartabat. Tak hanya itu, kegiatan ini juga akan menciptakan citra positif organisasi Koko Jali.

Dikutip dari media online voaindonesia. com, Koko Jali menggandeng generasi muda, yakni siswa-siswi SMA, sebagai peserta dari wisata toleransi Kampung Sawah. Generasi muda merupakan penerus kepemimpinan, serta harapan dari sebuah bangsa dan negara. Tolak ukur keberhasilan suatu negara atau bangsa tentunya dilihat dari keberhasilan generasi muda di masa yang akan datang. Untuk itu diperlukannya pendidikan karakter yang mumpuni sejak dini (Budiwibowo, 2016). 


\section{METODE PENELITIAN}

Teori negosiasi identitas yang dikemukan oleh Ting-Toomey, menjelaskan bahwa identitas atau konsep diri secara reflektif dilihat sebagai bagian teknis dari eksplanasi proses komunikasi interkultural. Identitas terbentuk dari konsep diri yang dikonstruksikan oleh individu dan lingkungan melalui pengalaman dan pengetahuannya, dan dikomunikasikan dalam satu budaya dan konteks interaksi sosial tertentu. Negosiasi identitas merupakan aktivitas komunikasi, konsep ini didefinisikan sebagai cara interaksi individu dalam pertukaran (transaksional) konsep diri dalam konteks situasi berbeda budaya. Individu-individu ini mencoba menjelaskan, mengubah, memaksakan, mendukung, atau melawan konsep diri yang diyakini olehnya atau pribadi lain. Negosiasi identitas pada individu menimbulkan dua sikap yakni mindless, dan mindful dalam menghadapi dinamika proses ini. Mindfulness merupakan satu proses "pemfokusan kognitif" yang dipelajari melalui latihan-latihan keterampilan yang dilakukan berulang-ulang.

Dengan menggunakan metode studi kasus, penelitian ini mengumpulkan data untuk menjelaskan secara mendalam mengenai strategi kehumasan Koko Jali melalui special event wisata toleransi dalam menanamkan nilai toleransi pada generasi muda yang menjadi peserta tur (Santoso \& Toruan, 2018). Studi Kasus juga merupakan metode yang ada dalam kelompok analisis kerja dan pengalaman individual serta perilaku institusi dalam hal ini Koko Jali dalam berinteraksi dengan para peserta tur. Studi kasus merupakan bagian dari metode analisis kualitatif yang menekankan pada peristiwa atau kasus-kasus khusus, yang tidak umum terjadi pada objek analisis (Satvikadewi, Danadharta, \& Aprianto, 2019). Penelitian ini bersifat kualitatif, yakni pengumpulan data dilakukan pada suatu konteks situasi alamiah, dan secara langsung terjun sendiri kelapangan untuk menemukan fakta dan data tersebut (Romli \& Romli, 2020). Berpangku pada paradigma interpretif, peneliti dapat mengkaji realitas sosial dengan komprehensif, dan menentukan apakah realitas tersebut hanyalah suatu simbol semu atau suatu fakta dan realitas dari suatu permasalahan (Sugiono, Suwitho, \& Suhermin, 2019).

Penelitian ini juga berpijak pada tradisi fenomenologi, yang menjelaskan bahwa pengetahuan seseorang timbul atau terbentuk dari kesadaran (consciousness) individu melalui pengalamannya secara internal, atau berkaitan dengan sifat-sifat alami pengalaman manusia, dan makna yang ada atau melekat padanya, atau melalui pemahaman individu terhadap objek atau kejadian melalui perspektif individu lain yang mengalaminya. Singkatnya, 
fenomenologi menjelaskan cara manusia untuk dapat memahami lingkungannya. (Haq, 2019) Melalui fenomenologi banyak bentuk-bentuk pengalaman langsung dari sudut pandang berbagai individu yang dapat dipelajari.

Fenomenologi dalam studi kasus memusatkan perhatian pada satu objek tertentu yang diangkat sebagai sebuah kasus untuk dikaji secara mendalam sehingga mampu membongkar makna realita di balik fenomena yang terjadi. Sehingga studi kasus dalam penelitian ini ialah menggali sesuatu yang tampak untuk menjadi pengetahuan (Indrayani \& Sunarto, 2019). Pada akhirnya, penelitian ini ditujukan untuk memahami pendekatan budaya dalam praktek kehumasan melalui program khusus/special event wisata toleransi.

Pengumpulan data dilakukan melalui wawancara langsung dan mendalam (indepth interview) dengan para penyelenggara wisata toleransi yakni dan pengurus Koko Jali yang dilangsungkan secara tatap muka di Bekasi. Tiga narasumbernya yakni Max Andrew selaku Founder Koko Jali, Ustad Taufik selaku pemuka agama dan pengurus dari Koko Jali, serta Ibu Yuningsih yang berfokus pada pengembangan program Koko Jali khususnya untuk anak berkebutuhan khusus. Selain itu peneliti juga mengambil data sekunder dari studi kepustakaan, dan data dari dokumen jurnal ilmiah maupun dokumen dari instansi terkait untuk kemudiaan ditelaah, dikaji, dan dipelajari lebih dalam serta melakukan interpretasi data untuk mencari solusi dalam permasalahan yang diangkat dalam penelitian ini.

\section{HASIL DAN PEMBAHASAN}

Komunitas Koko Jali, sudah berdiri sejak Oktober 2017, bermula dari rasa empati dua generasi muda, Max Andrew dan Eunike terhadap isu SARA di Pasar Baru, Jakarta Pusat. Akhirnya memunculkan inisiatif mereka untuk memulai aksi yang bernama "simpul damai jabodetabek" yang telah menuai partisipasi masyarakat setempat. Pada akhirnya gerakan tersebut berkembang dan diwujudkan nyata dalam bentuk wisata toleransi. Komunitas ini juga memberikan kita kesempatan terlibat dan memperkaya pengetahuan secara langsung akan keberagaman budaya dan agama yang biasanya hanya diketahui para pemuka agama. Tak hanya itu, Koko Jali pun kini memiliki spesialisasi program tur tematik mengenai nasionalisme, kebhinekaan, lingkungan, dan sosial. Sejalan dengan waktu, Koko Jali terus mengembangkan komunitas, dan program nya, serta membuat visi yakni memberikan layanan pendidikan yang menghargai keanekaragaman secara adil dan setara dalam pendidikan inklusif yang bermutu dan bermartabat.

Koko Jali menjadi komunitas biasa, namun 


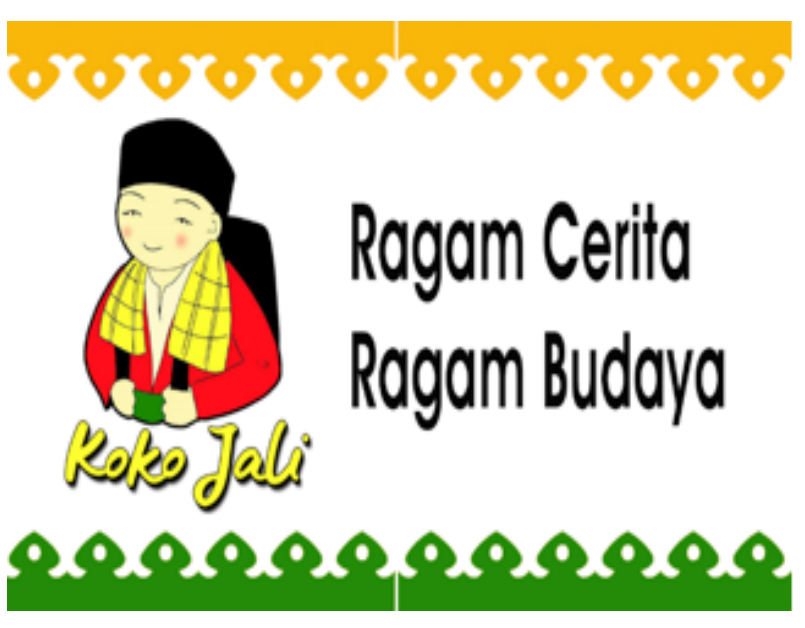

Sumber: Founder Koko Jali, 2020

\section{Gambar 3 Logo Komunitas Koko Jali}

sebuah wadah yang mengandung nilai-nilai sosial, sehingga memungkinkan para anggota atau individu yang terlibat di dalamnya mengumpulkan, memproses serta saling bertukar informasi dengan individu lain.

Pada akhirnya program yang diberikan Koko Jali bukan hanya sekedar wisata tematik, tapi juga memberikan tambahan program pemberdayaan maupun tempat diskusi dan pelatihan dalam paket wisata nya. Seperti yang dikatakan Founder Koko Jali, Max Andrew:

"Awal Koko Jali berdiri bersama saya Max dan Yuke, pada akhir oktober 2017. Awalnya hanya paket wisata, namun berkembang seiring waktu, untuk mewujudkan visi kami, akhirnya program kami bukan hanya paket wisata tematik tapi juga jadi sebuah program pemberdayaan maupun tempat diskusi dan pelatihan." (Bekasi, 14/02 /2020).

Melalui paket wisata tematik ini peserta dapatuntuk mengembangkan jiwa nasionalisme, empati, dan toleransi secara kreatif. Untuk mewujudkan nilai-nilai tersebut, tentu tim dari Koko Jali harus melakukan observasi dalam menentukan tempat wisata toleransi. Berikut penuturan dari Founder Koko Jali, Max Andrew:

"Saya melakukan survey, cari literasi, dan bertemu dengan orang-orang nya untuk menentukan destinasi wisata ini."

Wisatatematikinimenjadikonseppariwisata lokal yang identik dengan budaya masyarakat setempat. Secara tidak langsung, adanya objek wisata lokal mampu memberikan ciri khas bagi sebuah daerah karena merefleksikan hasil cipta, karsa, dan karya atas budaya masyarakat yang berbeda dengan wilayah lainnya. (Prastiani, Zuhriya, \& Pratiwi, 2020).

Konteks budaya menjadi faktor penting dalam kajian komunikasi (Kriyantono \& Sa'diyah, 2018). Oleh karena itu, wisata tematik yang dilakukan Komunitas Koko Jali ini merupakan program khusus yang dilakukan untuk memperdalam pemahaman komunikasi dan karakter yang dimiliki antarbudaya khusus nya antar agama (Kriyantono \& Sa'diyah, 2018). Dalam pengertian ini public relations atau humas sebenarnya merupakan bagian penting dalam organisasi yang mengelola dan bertanggung jawab terhadap keberhasilan dan kegagalan tindakan komunikasi yang diwujudkan dalam program wisata toleransi ini. Selain itu, dari sisi pemerintah setempat 
wisata toleransi ini juga dapat menjalankan fungsi kehumasan daerah tersebut yakni mempromosikan budaya yang telah dimiliki atau pencapaian positif kepada masyarakat luas baik melalui media massa maupun online melalui publikasi yang didapatkan. Intinya fungsi kehumasan bertugas untuk membawa organisasi/instansinya, masyarakat umum dan pemerintahan ke hubungan yang lebih harmonis.

Komunikasi antar budaya dalam wisata toleransi Kampung Sawah, memerlukan proses negosiasi atau pertukaran identitas antara warga Kampung Sawah, khususnya tokoh agama setempat sebagai narasumber kredibel yang telah ditentukan Koko Jali, dengan para peserta tur.

Negosiasi identitas dikatakan efektif jika kedua belah pihak merasa dipahami, dihormati, dan dihargai (Kurniasari, 2015). Koko Jali mengadakan wisata tematik ini dikarenakan peserta dirasa akan lebih mudah untuk mengerti dan menerapkan toleransi setelah melihat 'fakta sosial' secara langsung dan terlibat secara nyata di lingkungan Kampung Sawah yang telah menerapkan toleransi antar umat-beragama dalam kehidupan keseharian masyarakat nya. Berdasarkan sudut pandang etnometodologis, 'fakta sosial' tercipta karena adanya aktivitas atau aksi interpretif dari setiap anggota masyarakat, dimana aktivitas tersebut menjadi wahana bagi aktor yang melihatnya untuk memproduksi dan mengorganisasikan hal tersebut dalam kehidupan sehari-hari itu sendiri (Malik, 2017). Dalam menghadapi dinamika proses ini, individu yang terlibat didalam nya harus bersikap mindful, dan untuk mencapai mindfulness diperlukan manajemen interaksi yang baik.

Manajemen interaksi yakni cara mengelola aspek-aspek prosedural dari suatu percakapan, seperti kemampuan untuk mengawali suatu percakapan. Manajemen interaksi juga memfokuskan pada kemampuan untuk berorientasi kepada orang lain dalam suatu percakapan, seperti memberi perhatian penuh dan bersikap responsif (Mas'udah, 2014). Sejalan dengan fungsi humas yang tak terbatas hanya pada kegiatan komunikasi dalam bentuk penyebaran informasi saja, tetapi harus terjadi sharing informasi, pertukaran informasi, atau komunikasi dua arah, yang dalam hal ini akhirnya melahirkan negosiasi identitas (Nugraha, Komariah \& Subekti, 2014).

Sehari sebelum melakukan wisata toleransi Kampung Sawah, para peserta, yakni sekitar 50 siswa-siswi SMA/SMK dikumpulkan dan yang akan dilakukan, serta pelatihan penulisan, dan bagaimana cara menggunakan sosial media yang baik, agar para peserta bijak menggunakannya terutama saat kunjungan wisata nanti. Hal ini merupakan salah satu upaya awal untuk menciptakan mindfulness, yakni 
tentang menawarkan perhatian, penerimaan, dan penegasan identitas yang tidak terbagi, dan penyelarasan antarpribadi yang menjangkau proses hubungan dengan orang lain yang berbeda budaya (Dalil \& Rahardjo, 2019). Seperti yang diungkap Max Andrew, founder dari Koko Jali:

"Para peserta kita kumpulin satu hari sebelum berangkat, lalu kita kasih training, pelatihan penulisan, bagaimana menggunakan media social yang baik. Setelah training baru mereka jalan mengikuti wisata toleransi. Kurang lebih 50 peserta, tersebar di beberapa sekolah".

Wisata toleransi ini dilaksanakan dengan mengunjungi empat tempat yaitu Gereja Katolik Santo Servatius, Gereja Kristen Pasundan, Masjid Aljahuar Yasfi, dan Rumah Panti Asuhan Yayasan KDM. Sebelum memulai tur dan saat mengawali memasuki rumah ibadah, peserta diberi kebebasan selama mengikuti rangkaian acara, hal ini diungkap oleh founder Koko Jali, Max Andrew:

"Kami juga setiap kali tur, menghargai teman-teman jika selama di perjalanan ada yang tidak mau masuk ya tidak apaapa. Kami memberi kebebasan, tidak ada paksaan".

Wisata Toleransi di dalam Gereja Servatius Kampung Sawah, Wisata toleransi ini dimulai dan dipandu langsung oleh Koko Jali, Max Andrew pada pukul 8.30 WIB. Titik kumpul pertama bertempat di Saung Maria lama, para pesertapun langsung mendapat sambutan dari Romo Wartaya, SJ dan dilanjutkan dengan

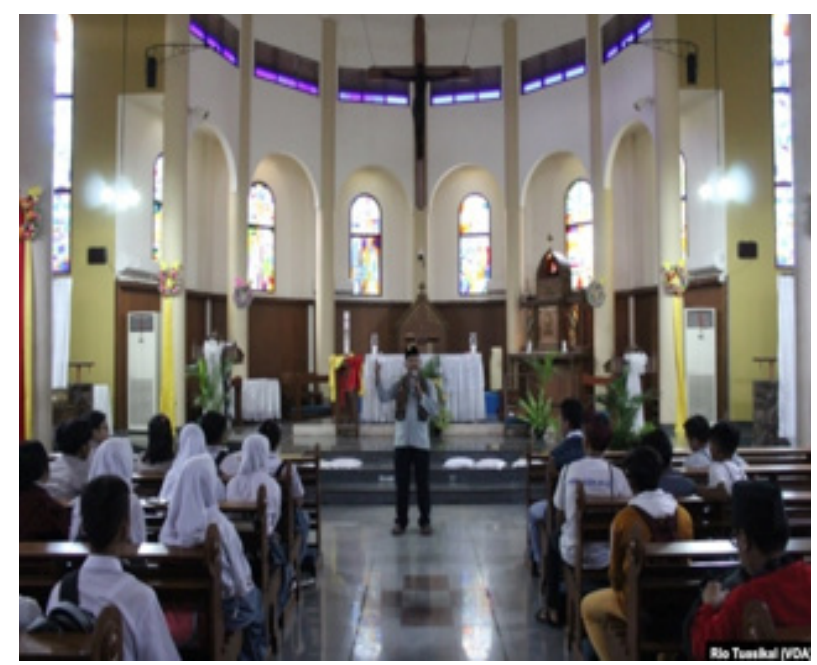

Wisata Toleransi di dalam Gereja Servatius Kampung Sawah, 2019

\section{Gambar 4 Kegiatan pemaparan kepada peserta Kegiatan}

menyanyikan lagu Indonesia Raya. Penampilan dari Sisilia Choir juga turut meramaikan pembukaan wisata toleransi tersebut. Lagu Betawi pun dilantunkan, lagu ini biasanya dinyanyikan saat perayaan ibadah umat Katolik (Misa) setiap bulan nya. Seperti pada gambar 4, terlihat para peserta wisata toleransi yang terdiri dari siswa-siswi SMA sedang mendengarkan pemaparan yang dibawakan oleh Wakil Ketua Dewan Paroki Gereja Servatius Kampung Sawah, bapak Matheus Nalih Ungin. Beberapa siswi terlihat mengenakan jilbab yang merupakan atribut keagamaan islam dalam rumah ibadah umat Katolik (Anafarhanah, 2019). Tak hanya peserta, terlihat pula atribut yang dikenakan oleh tokoh agama bapak Matheus seorang beragama nasrani bernuansa adat betawi dan islami, yakni peci dan sarung. 
Beliau menyatakan penggunaan peci atau penutup kepala yang identik bagi lelaki Islam ini, pada perkembangannya telah menjadi identitas untuk sebagian penduduk Indonesia, tanpa memandang agama dan kepercayaan yang mengenakannya. Seperti yang dipakai oleh anggota Krida Wibawa yaitu pengawal misa di gereja Servatius disetiap minggunya. Jemaat menggunakan peci juga sebagai bentuk kesetaraan, serta simbol bahwa dia membela rakyat sesuai paham Pancasila yang ia pahami, yang mana simbol ini sudah terkonstruksi sejak jaman Soekarno. Dengan filosofi memperjuangkan keadilan, persamaan hak, dan memperjuangkan kepentingan kaum tertindas untuk menghapuskan pemerasan dan mempersatukan semua golongan yang tertindas (Kertamukti, 2013). Berkenaan dengan busana atau atribut yang dikenakan oleh tokoh agama Bapak Matheus Nalih Ungin tersebut, tak hanya menyuratkan identitas agama, namun juga peran sosial sebagai bagian dari masyarakat yang tolerir terhadap perbedaan keyakinan yang ada/pluralisme. Tak hanya beliau, tetapi sebagian umat Kristen Katolik yang hadir dalam ibadah berdasarkan pengalaman narasumber di lapangan turut menggunakan sarung, peci, batik. Sekilas tidak ada bedanya dengan umat Muslim. Namun, tata cara ibadah tetap dilakukan sesuai dengan agama masingmasing.
Tujuan selanjutnya adalah Gereja Kristen Pasundan. Bapak Pendeta, Ibu majelis dan beberapa jemaat lainnya menyambut rombongan peserta tur. Sejarah gereja menjadi hal pertama yang diungkapkan, selama 145 tahun gereja berdiri menandakan faktor historis menjadi hal yang begitu melekat di Kampung Sawah. Budaya toleransi yang ada sudah turuntemurun terjadi, kekerabatan antar jemaat gereja dan umat muslim, hingga penggunaan bahasa sunda/betawi dengan iringan musik keroncong pada saat ibadah.

Setelah diskusi dengen pemuka agama Gereja Kristen Pasundan, rombongan melanjutkan perjalanan menuju Masjid Aljahuar Yasfi. Dialog dibuka oleh salah satu ustad sekaligus pengurus masjid persis di teras rumah abah (guru besar/kiai). Beliau mengawalinya dengan menceritakan beberapa karya warga Kampung Sawah seperti SKS, siaran radio, PUB yang dibentuk untuk menjaga keutuhan Kampung Sawah dan mengantisipasi adanya kekerasan yang datang dari luar. Pemakaian busana Betawi yang dikenakan orang asli Kampung Sawah juga bukan bersifat agamais melainkan budaya.

Kebebasan beragama dapat ditafsirkan secara berbeda-beda oleh berbagai kebudayaan. Menurut Pasal 9 ECHR, kebebasan beragama atau kepercayaan dapat terbagi menjadi dua bagian yaitu kebebasan untuk memilih 
atau menganut agama atau kepercayaan atas keinginannya sendiri (forum internum) dan kebebasan untuk memanifestasikan agama dan kepercayaan yang dianutnya (forum eksternum). hak untuk beragama ditentukan oleh dirinya sendiri dan tanpa ada paksaan dan dipaksakan oleh orang lain (Putri, 2011). Sejalan dengan hal tersebut, founder dari Koko Jali menyatakan, "masih banyak pribadi di luar yang belum teredukasi mengenai hal tentang kebebasan beragama, bahkan ada yang sudah teredukasi namun tidak bergerak melakukan action, tidak menerapkan nya, maka dari itu kami ingin menjadi salah satu yang menggerakan kegiatan toleransi ini, agar setidaknya generasi muda kedepannya bisa lebih baik lagi dengan budaya baru yang telah tertanam sejak dini yakni toleransi."

\section{Dalam Mencapai komunikasi yang} mindful, Jandt mengungkapkan 4 kecakapan dalam menghadapi negosiasi identitas antar budaya. Yang pertama, kekuatan kepribadian (personality strength), setiap peserta tentu memiliki kepribadian yang berbeda satu dengan lain nya. Para peserta yang sudah memutuskan dan mendaftar untuk ikut wisata toleransi ini tentu sudah menunjukan kekuatan kepribadian yang berani dan terbuka (open minded), atau pun sudah mulai mau membuka hatinya untuk mengenal budaya dan agama lain, serta sudah memiliki pemahaman toleransi yang cukup baik.. Sejalan dengan penuturan Max Andrew, founder dari Koko Jali:

"Yang ikut yang memang mungkin saya rasa sudah memiliki pemahaman nilai toleransi yang cukup bagus ya, walaupun ada juga yang belum pernah masuk-masuk rumah ibadah agama lain, tapi mereka mulai membuka hati untuk melakukan hal tersebut."

Hal ini kepribadian juga merujuk pada kemampuan untuk berperilaku sesuai dengan konteks yang berbeda-beda. Kemampuan berbeda dari para peserta inilah yang memberikan pengaruh serta inspirasi tidak hanya pada peserta bahkan pada anggota komunitas Koko Jali, seperti yang diutarakan Ustad Taufik, salah satu pengurus Koko Jali, yakni Ketua pada program Toleransi Antar Sekolah:

"Pada saat tur, saya bertanya kepada peserta yang non-muslim, kenapa anda ikut ini? Dia tunanetra, menjawab mau pegang bedug, mau dengar suaranya, padahal beliau non-muslim. Di situ membuat hati saya terenyuh."

Kedua, kecakapan komunikasi (communication skills), kecakapan-kecakapan komunikasi antarbudaya mensyaratkan kemampuan berkaitan dengan pesan (Mas'udah, 2014), seperti cara peserta menyampaikan pesan, dan memberikan umpan balik dengan tokoh agama maupun warga Kampung Sawah, baik secara tatap muka, atau dengan berbagai media, termasuk media daring. Dalam kegiatan wisata toleransi, peserta diajak untuk mengunjungi rumah-rumah ibadat di Kampung Sawah, dan terlibat dalam dialog dengan tokohtokoh agama setempat. Seperti yang dijelaskan 
oleh Founder Koko Jali, Max Andrew:

"Kita bahas tata cara keagamaan, keunikan, dan artinya, tiap-tiap rumah ibadat yang kita singgahi. Yang menjadi speakers nya ya tokoh agama nya sendiri. Contoh, kalau di gereja pasundan, ada seserahan dulu, dikumpulkan dan didoakan. Sebagai syukuran tahunan. Jemaat membeli pisang, dan lain-lain untuk didoakan. Setelah itu ke masjid, mereka cerita tentang keluarga yang berbeda, perkawinan campur. Mereka ceritakan pohon keluarga dan adat istiadat tetap dipertahankan. Satu keluarga namun berbeda agama."

Selain itu, melalui wadah yang disediakan Koko Jali ini, para peserta bisa lebih bebas menyampaikan pendapat ataupun pertanyaan yang selama ini tidak bisa dinyatakan dengan gamblang di luar. Seperti contoh yang diungkap Max Andrew founder Koko Jali:

"Justru mereka banyak bertanya pergumulan mereka, misal sebenarnya selama ini saya mau tanya sebenarnya betul ga sih agama hindu ada kasta, seperti itu contohnya. Dah itukan pertanyaanpertanyaan yang takut menyinggung apabila ditanyakan di lingkup awam, nah dengan ada forum ini mereka bisa langsung tanyakan di sini. Ternyatakan di umat Hindu tidak ada kasta melainkan warna, maksudnya perbedaan profesi atau jabatan. Jadi seperti itu, membuka paradigma yang baru lalu mereka menyampaikan lagi kepada orang lain, teman-teman nya, atau di komunitasnya."

Melalui bekal informasi-informasi yang didapat tersebut, para peserta lebih mudah untuk berinteraksi dengan lawan bicara berbeda agama lain karena memiliki kecakapan informasi yang baik. Cara penyampaian pesan tersebut merujuk pada kemampuan untuk memahami dan menggunakan bahasa serta memberikan umpan balik. Seperti beberapa cara penyampaian pesan yang disebutkan oleh narasumber:

"Kami berikan juga pengajaran untuk pemeluk agama yang tidak sama, kami tidak bilang kafir. Kami hanya bilang berbeda." (Max Andrew, founder Koko Jali).

Demikian pula hal nya yang disampaikan

Ustad Taufik,

"Saya ya sederhana saja, saya dari muslim, satu yang saya ingat betul, guru saya mengatakan jangan lihat agama nya, tapi lihat orang nya, manusia nya. Siapa yang menciptakan manusia, ya Tuhan. Itu yang saya tanamkan berulang-ulang kepada anak didik saya dan para peserta tur" (Ustad Taufik, Penanggung jawab program toleransi antar sekolah).

Tore Lindholm menyatakan yang terutama adalah para pihak dapat mendukung doktrin publik tentang martabat inheren setara dan kebebasan semua manusia, yang tidak dapat dicabut tanpa tergantung dengan pandangan agama, hidup, atau perbedaan lain pada diri mereka dan masing-masing pihak mau memahami dan mempercayai bahwa pihak lain juga sama-sama mendukung kebebasan beragama atau berkeyakinan yang umum bukanlah para pemeluk agama menghargai kepercayaan dan pengamalan agama lain atau apakah mereka mengakui jalan keselamatan alternative.

Agar menjadi seseorang yang pengertian (mindful) berarti bahwa memiliki keterbukaan terhadap informasi baru dan memiliki beragam perspektif budaya yang dapat menciptakan 
variasi kategori untuk memahami cara pandang budaya orang lain, yang akhirnya membawa kita pada kategori selanjutnya yakni penyesuaian psikologis.

Poin ketiga dari empat kecakapan yang disebutkan Jandt, yakni penyesuaian psikologis (psychological adjustment). Sensitifitas tentu diperlukan dalam proses komunikasi atau pertukaran makna yang kompleks dari satu individu ke individu lain, yang memiliki latar belakang budaya berbeda-beda. Hal ini tampak dalam bentuk rasa empati dan pemeliharaan identitas. Empati adalah kemampuan untuk berpikir dan merasakan sama seperti orang lain. Pintu empati harus dibuka oleh kedua belah pihak untuk mengukur kenyamanan situasi komunikasi.(Iskandar, 2004). Seperti yang diungkapkan Ustad Taufik:

"Kita yang sebenarnya pegal karena bawa orang, tapi melihat mereka seneng jadi bawaan nya ikut happy. Jadi ngobrol pun juga asyik aja."

Mengedepankan empati sosial dan memunculkan sepenanggungan dalam berbuat dan berpikir sangat penting untuk mewujudkan harmoni (keselarasan) hidup antarsesama umat manusia, terutama dalam mewujudkan pendidikan toleransi antar umat beragama. Empati sosial yakni kesadaran identitas sosial setiap individu dalam meningkatkan kapasitas empati yang sebenarnya. hal ini dapat dilakukan dengan lebih menambah kesadaran diri (selfaware autonomy) dan mengurangi tendensi mengklaim apa yang benar dan apa yang salah. kesadaran diri/mawas diri bahwa setiap orang memiliki keunikan, kelebihan, dan kekurangan yang dapat saling melengkapi (Rosyid, 2015).

Ustad Taufik juga menambahkan,

"terkadang dari peserta ada yang berkebutuhan khusus, dan kita yang terlahir sempurna justru banyak belajar dari mereka. Waktu itu ada peserta yang tuna netra, namun semangatnya untuk mengeksplorasi budaya dan agama membuat kami kagum, tidak ada capek nya selama perjalanan, saya sendiri yang awal nya lelah melihat semangat nya jadi merasa termotivasi, begitu pula peserta lain. Karena melihat dan berinteraksi secara langsung ya, maka energi positif tersebut bisa langsung terasa lebih kuat. Kami di sini, bukan hanya peserta belajar dengan pemuka agama, tapi peserta dengan sesama peserta pun saling belajar, mengerti, memahami keadaan satu sama lain, karena ini sifatnya kan trip kelompok, kita berjalan ramai-ramai, kita harus saling memperhatikan teman kelompok, yang tentu latar belakang dan indentitasnya pun berbeda-beda. Kami pun panitia juga ikut belajar dari pesertapeserta, semangatnya tinggi, rasa ingin tahu nya tinggi, punya ketulusan hati, mau belajar, dan mau mendengarkan."

Dalam sesi wisata toleransi, para peserta diajarkan untuk memperhatikan rekan seperjalanan atau kelompoknya, mereka juga terlibat diskusi dengan topik-topik yang sudah diberikan. Interaksi antar anggota kelompok tersebut menumbuhkan pemahaman akan satu anggota dengan anggota lain nya, mereka saling mempertukarkan identitas melalui percakapan tersebut. Setelah memiliki kesadaran akan 
identitas, selanjutnya adalah cara untuk melakukan pemeliharaan akan identitas tersebut yang perlu diterapkan dari masing-masing pribadi, dan diharapkan dapat memberikan pengaruh juga kepada lingkungan keseharian para peserta.

Pemeliharaan identitas adalah kemampuan untuk memelihara identitas mitra interaksi dengan mengkomunikasikan kembali pemahaman yang akurat tentang identitas. Seperti yang diungkapkan Ustad Taufik:

"Saya saja yang muslim sampai takjub, ada dosen non-muslim yang menjadi peserta, sangat totalitas dalam mencari tahu dan membuktikan sendiri mengenai keberagaman. Saat saya tanya apa alasan ikut tur, dia menjawab Agar kalangan mahasiswa saya tidak berantem lagi, saya bisa ceritakan keragaman di Jakarta dan sekitarnya benar-benar ada, saya sudah lihat langsung."

Selain keinginan dari peserta yang ingin mengkomunikasikan kembali pemahaman mengenai identitas yang didapat, Koko Jali juga menyediakan waktu sebelum mengakhiri perjalanan tur untuk saling diskusi dan bertukar pikiran, yakni mengungkapkan kembali pengertian keberagaman apa yang sudah didapat, informasi serta hal baru apa yang menarik dan membuat mereka terkesan, serta lebih menghargai perbedaan. Tujuan nya agar setiap tokoh agama dan penggagas wisata toleransi dari Koko Jali, dapat memastikan informasi yang diterima sudah akurat tentang identitas tersebut, serta mengasah dan menstimuli kemampuan peserta untuk dapat mengkomunikasikan kembali pemahaman mereka kepada orang lain.

Seperti yang diungkap Max Andrew selaku founder Koko Jali:

"Setelah ikut acara dan kegiatan, mereka liat, setelah itu ada diskusi, kita bertukar pikiran. Kita juga ada beberapa tokoh agama juga yang membahas tentang lingkungan. Mereka jadi terinspirasi satu sama lain. Ada tokoh agama islam dan katolik juga."

Hal ini lakukan oleh Koko Jali untuk menjadikan para peserta wisata toleransi ini dapat menjadi agen perdamaian serta perpanjangan tangan dari Koko Jali meneruskan visi nya yakni, memberikan pendidikan yang menghargai keanekaragaman secara adil dan setara, di lingkungan mereka masing-masing. "Pada dasarnya perjuangan toleransi tidak harus hanya dilakukan salah satu lembaga instansi, tapi harus diperjuangkan oleh masyarakat semuanya. Intinya mereka yang ikut menjadi peace maker di lingkungan nya. Mereka dari yang punya pergumulan masing-masing, dan setelah mereka ikut tur ini mereka dapat jawaban, lalu menyampaikan bagaimana gerakan perdamaian harus dilakukan”.

Poin keempat, kesadaran budaya (cultural awareness), individu yang saling berinteraksi harus memahami kebiasaan-kebiasaan sosial dan budaya, serta sistem-sistem sosial dan budaya dari rekan interaksi. Pada dasarnya ketidaktahuan akan suatu budaya baru atau jika individu harus dihadapkan pada situasi dengan perbedaan latar belakang budaya akan 
menimbulkan kecemasan dan ketidakpastian dalam dirinya. Bagi kebanyakan orang, interaksi dengan orang yang berasal dari budaya atau kelompok etnis lain merupakan situasi yang baru (novel situation) (Primasari, 2014). Situasi yang baru tersebut dicirikan oleh munculnya tingkat ketidakpastian dan kecemasan yang tinggi, hal tersebut merupakan sebab mendasar dari kegagalan komunikasi antarbudaya.

Salah satu upaya yang dapat dilakukan untuk mengurangi ketidakpastian adalah dengan mencari informasi. Pencarian terhadap informasi ini dapat dilakukan melalui tiga strategi, yang mana melalui kegiatan wisata toleransi oleh Koko Jali, ketiga strategi tersebut diterapkan dengan baik. Yang pertama strategi pasif (passive strategy), yakni peserta dapat melakukan pengamatan kepada peserta lain atau narasumber pemuka agama yang menjadi lawan bicara mereka. Mereka dapat mengamati bagaimana individu memberikan respon pada pembicaraan, dan berperilaku. Selanjutnya strategi aktif (active strategy) yakni peserta dapat langsung bertanya kepada para pemuka agama sebagai pihak ketiga untuk mengetahui informasi mengenai orang lain tidak secara langsung. Terakhir, strategiinteraktif(interactive strategy) yakni peserta dapat bertanya secara langsung, melakukan pengungkapan diri, dan menunjukkan perilaku yang menenangkan dan menimbulkan kenyamanan selama diskusi atau berinteraksi dengan peserta lain nya maupun narasumber. Ibu Yuningsih turut menambahkan terkait strategi aktif dan interaktif tak hanya berlangsung dengan narasumber atau pemuka agama, tetapi dengan setiap peserta atau setiap individu yang terlibat,

"Ada juga wisata yang melibatkan peserta dari anak-anak berkebutuhan khusus, dan ada beberapa sukarelawan dan orangtua yang turut membantu menuntun atau mendampingi peserta. Nah disitu mereka aktif saling bertukar cerita, bertanya, saling membantu. Mereka sama-sama memberikan energi yang positif dalam kegiatan ini."

Memahami bagaimana orang berpikir dan berperilaku merupakan sesuatu yang esensial untuk berkomunikasi antarbudaya secara efektif.

Pada akhirnya pemahaman dan kesadaran situasi sosial dan budaya ini memunculkan keluwesan dalam bersikap yang merujuk pada kemampuan untuk berperilaku sesuai dengan konteks yang berbeda-beda. Seperti hal nya yang diungkapkan Ustad Taufik:

"Masuk ketempat ibadah, itu sakral sekali. Seperti ada yang harus pake selendang, wanita berhalangan tidak boleh masuk. Harus menghormati apa yang menjadi aturan dan tata cara ibadah masing-masing agama. Bagaimana cara ambil wudhu saat ke masjid. Lalu saya ke gereja, yang menurut saya menarik, ibadah nya pake keroncong, itu hal baru bagi saya. Dan saya kagum ternyata gereja sangat nasionalis dan mencintai budaya Indonesia dengan menjadikan budaya musik keroncong itu sebagai elemen ibadah. Jadi buat saya budaya-budaya seperti ini harus dipahami dan dipertahankan."

Dalam kehidupan bermasyarakat di 
Indonesia menganut paham demokrasi, yakni paham dimana masyarakat memiliki hak untuk mengaspirasikan pendapatnya, bebas bisa melakukan apa saja selama tidak melanggar aturan dan norma yang berlaku, juga masyarakat dilindungi hak dan kebebasannya untuk beribadah sesuai dengan ajaran agama yang dianutnya (Marta, 2017).

Contoh lainnya seperti seorang beragama Hindu terganggu dengan kegiatan pemotongan hewan kurban seperti sapi (dalam Agama Hindu, sapi merupakan binatang yang suci), ketidaktahuan wisatawan atau individu akan budaya lokal bisa mengakibatkan ketidaknyamanan. Tetapi apabila wisatawan asal negara lain yang beragama Hindu sudah mengetahui budaya tersebut, dan tetap memutuskan datang ke Indonesia pada saat hari Idul Adha artinya wisatawan telah memahami perbedaan budaya yang ada (Marta \& Supina, 2017). Oleh karena itu saling belajar memahami budaya satu sama lain dapat mengurangi konflik akibat ketidakpastian dan kekhawatiran yang ditimbulkan oleh adanya perbedaan latar belakang budaya.

\section{SIMPULAN}

Dari uraian pembahasan yang telah dijelaskan sebelumnya, maka dapat disimpulkan bahwa wisata toleransi yang diadakan oleh Koko Jali berperan penting dalam menciptakan dan membentuk agen perdamaian yakni generasi muda yang menjadi para peserta tur. Dengan melakukan manajemen interaksi yang baik, mencakup yang pertama, pengelolaan aspek-aspek prosedural dari suatu percakapan, di mana hal ini melibatkan aspekaspek kecakapan menuju komunikasi yang mindful menurut Jandt di dalam nya, yakni kekuatan kepribadian (personality strength), dan kecakapan komunikasi (communication skills). Kedua, manajemen interaksi yang dilakukan juga memfokuskan pada kemampuan untuk berorientasi kepada orang lain dalam suatu percakapan, seperti memberi perhatian penuh, empati, dan bersikap responsif. Pada manajemen interaksi kedua ini juga melibatkan aspek kecakapan penyesuaian psikologis (psychological adjustment), dan adanya kesadaran budaya (cultural awareness) yang membuat seorang memiliki sikap mindful dalam melakukan komunikasi lintas agama.

Melalui peran kehumasan yang dilakukan Komunitas Koko Jali dalam mempertukarkan nilai keberagaman melalui wisata toleransi di Kampung Sawah ini, banyak bentuk-bentuk pengalaman langsung dari berbagai sudut pandang tokoh agama, generasi muda sebagai peserta, dan individu lain nya yang terlibat dapat dipelajari. Sehingga membuka wawasan dan pengetahuan, serta awareness terhadap keberagaman agama di Indonesia. Para peserta 
semakin mengetahui dunia dari cara atau sudut pandang orang yang mengalaminya secara langsung, yakni warga Kampung Sawah, atau berkaitan dengan sifat-sifat alami pengalaman manusia, dan makna yang ada atau melekat padanya. Secara lebih mendalam, wisata toleransi ini mampu membongkar makna realita toleransi antar agama di balik fenomena keberagaman dan konflik agama yang terjadi. Sehingga studi kasus dalam penelitian ini ialah menggali sesuatu yang tampak untuk menjadi pengetahuan (Indrayani \& Sunarto, 2019).

Wisata tematik bertemakan toleransi ini diharapkan mampu menginspirasi organisasi, komunitas, maupun instansi sosial di Indonesia untuk membuat program yang kaya akan budaya dan nilai-nilai toleransi antar budaya, serta dapat menjadi literasi bagi penelitian selanjutnya.

\section{DAFTAR PUSTAKA}

Anafarhanah, S. (2019). Tren busana muslimah dalam perspektif bisnis dan dakwah. Jurnal Ilmu Dakwah, 18, 81-90. https://doi. org/10.1119/1.2218359

Budiwibowo, S. (2016). Membangun pendidikan karakter generasi muda melalui budaya kearifan lokal di era global. Premiere Educandum : Jurnal Pendidikan Dasar Dan Pembelajaran, 3(01), 39-49. https://doi.org/10.25273/pe.v3i01.57

Dalil, F., \& Rahardjo, T. (2019). Peran sesepuh adat dan media komunitas masyarakat kasepuhan Ciptagelar dalam menjaga identitas kebudayaan asli. Interaksi Online, 7(3). https://doi.org/10.1017/ CBO9781107415324.004

Devi, S. S. V., \& Rahardjo, T. (2018). Isu identitas etnis dan agama dalam kontes politik (kasus pemilihan gubernur Sumatera Utara 2018). Interaksi Online, 7(4).

Haq, I. B. (2019). Henna sebagai komunikasi identitas budaya (studi fenomenologi pemahaman \& pemaknaan laki-laki pengguna henna di Kampung Arab Surabaya). VoxPop, 1(1), 98-107. Retrieved from http://voxpop.upnjatim.ac.id/index. $\mathrm{php} /$ voxpop/article/view/16

Indrayani, H., \& Sunarto. (2019). Fandom: marketing communication strategy 3 . 0 to strengthen the fantation of nationalism through sports. Bricolage : Jurnal Magister Ilmu Komunikasi, 5(1), 15-30. https://doi. org/10.30813/bricolage.v5i01.1741

Iskandar, D. (2004). Identitas budaya dalam komunikasi antar-budaya: kasus etnik Madura dan Etnik Dayak. Jurnal Masyarakat Dan Budaya, 6(2), 119-140. https://doi.org/10.14203/jmb.v6i2.208

Ismanto, K., Huda, M., \& Maulida, C. (2013). Transformasi masyarakat petani mranggen menuju masyarakat industri. Jurnal Penelitian, 9(1). https://doi.org/10.28918/ jupe.v9i1.129

Jamaludin, A. N. (2015). Sistem kekerabatan masyarakat Kampung Sawah Di Kota Bekasi. El-HARAKAH, 17(2), 259. https:// doi.org/10.18860/el.v17i2.3347

Kertamukti, R. (2013). Komunikasi simbol: peci dan pancasila.JURNAL KOMUNIKASI PROFETIK, 6(1), 53-66.

Kriyantono, R., \& Sa'diyah, H. (2018). Kearifan lokal dan strategi komunikasi public relations di bumn dan perusahaan swasta. Jurnal ILMU KOMUNIKASI, 
15(2), 171-188. https://doi.org/10.24002/ jik.v15i2.1480

Kurniasari, N. D. (2015). Negosiasi identitas penarik becak wanita. Jurnal Komunikasi Islam, 9(2). https://doi.org/10.21107/ ilkom.v9i2.1205

Malik, A. (2017). Seren taun sebagai medium komunikasi adat. Lontar, 5(1), 1-16. https://doi.org/10.30656/lontar.v5i1.482

Marta, R. F. (2017). Polemik kebhinnekaan Indonesia padainformasiinstagram@infia fact terkait patung kwan sing. Bricolage: Jurnal Magister Ilmu Komunikasi, 3(2), 63-71. https://doi.org/10.30813/bricolage. v3i02.922

Marta, R. F., \& Supina. (2017). Gegar budaya Nusantara.

Mas'udah, D. (2014). Mindfulness dalam komunikasi antarbudaya (studi deskriptif pada peserta Indonesia-Poland crosscultural program). Jurnal Profetik, 7(2), 77-89. https://doi.org/10.24198/jkk. volln1.9

Noorbani, M. A. (2019). Kerukunan umat beragama di Kampung Sawah Kecamatan Pondok Melati Kota Bekasi. Jurnal AlQalam, 25(2). https://doi.org/10.1017/ CBO9781107415324.004

Nugraha,A.R.,Komariah,K\&Subekti,P.(2014). Fungsi humas pemerintah Kabupaten Sumedang dalam mengkampanyekan Sumedang sebagai puseur budaya Sunda (Spbs). Edutech, 13(1), 34. https://doi. org/10.17509/edutech.v13i1.3220

Prastiani, N., Zuhriya, R., \& Pratiwi, B. (2020). Promosi dan pemasaran pariwisata objek wisata Tirta Sinongko dalam upaya menarik wisatawan. Profesi Humas, 5(1), 38-57.

Primasari, W. (2014). Pengelolaan kecemasan dan ketidakpastian diri dalam berkomunikasi studi kasus mahasiswa perantau UNISMA Bekasi. Jurnal Ilmu Komunikasi, 12(1), 26-38. https://doi. org/10.31315/jik.v12i1.355

Putri, N. S. (2011). Pelaksanaan kebebasan beragama di Indonesia (external freedom) dihubungkan ijin pembangunan rumah ibadah. Jurnal Dinamika Hukum, 11(2). $\quad$ https://doi.org/10.20884/1. jdh.2011.11.2.183

Romli, R., \& Romli, N. A. (2020). Implementasi strategi komunikasi “ Bandung Juara " sebagai bagian dari city branding Kota Bandung. Profesi Humas, 4(2), 263-289. https://doi.org/10.24198/prh.v4i2.23547

Rosyid, M. (2015). Antar-umat beragama di Kudus: belajar dari konflik tolikara Papua 1 syawal 1436 H/ 2015 M. (2). https://doi. org/10.21043/quality.v3i2.1915

Santosa, B. A. (2017). Peran media massa dalam mencegah konflik. Jurnal Aspikom, 3(2), 199-214. https://doi.org/doi.org/10.21107/ ilkom.v11i1.3020

Santoso, P. Y., \& Toruan, R. R. M. L. (2018). Strategi marketing public relations dalam rebranding hsbc Indonesia untuk membentuk brand awareness. Jurnal Pustaka Komunikasi, 1(1), 1-14.

Satvikadewi, A. A. I. P., Danadharta, I., \& Aprianto, B. (2019). Keberlanjutan jurnalistik sehat di era konvergensi daring suarasurabaya.net dengan pendekatan engagement pyramid. Bricolage: Jurnal Magister Ilmu Komunikasi, 5(02), 177. https://doi.org/10.30813/bricolage. v5i2.1855

Sicca, S.P., \& Rakhmat, M. Y. (2016). Negosiasi identitas hizbut tahrir indonesia (hti) dalam mengkomunikasikan gagasan alternatifnya kepada kelompok mayoritas. Jurnal Interaksi Online, 4(1).

Sugiono, S., Suwitho, S., \& Suhermin, S. (2019). 
Penentu brand awareness pada aplikasi ojek online (gojek). Master of Management Journal Unram, 8(3), 280-294. https://doi. org/10.29303/jmm.v8i3.442

Suryandari, N. (2017). Eksistensi identitas kultural di tengah masyarakat multikultur dan desakan budaya globaL. Jurnal Komunikasi, XI(01), 21-28. https://doi. org/10.21107/ilkom.v11i1.3020
Tamburian, H. . D. (2018). Komunikasi lintas budaya masyarakat dayak dalam menjaga kerukunan hidup umat beragama. Jurnal Komunikasi, 10(1), $77 . \quad$ https://doi. org/10.24912/jk.v10i1.1220

Wahjusaputri, S., \& Fitriani, S. (2016). Religious harmony in Indonesia (learning harmony and religious tolerance of Kampung Sawah society in Bekasi City). 